\title{
ВИДИ ФОРМ І ЗАСОБІВ ПЕРЕДВИБОРНОЇ АГІТАЦІЇ НА ПАРЛАМЕНТСЬКИХ ВИБОРАХ: УКРАЇНСЬКА ПРАКТИКА ТА ЗАРУБІЖНИЙ ДОСВІД
}

Волошенюк Н. М.

У статmі піднімається питання про роль передвиборної агітації на парламентських виборах. Розглянуто форми та засоби ї̈ здійснення на виборах народних депутатів України, які передбачені та доволі детально врегульовані Законом України «Про вибори народних депутатів України», такі як мітинги, походи, демонстрації, пікети, концерти, вистави, спортивні змагання, демонстрація фільмів тощо. Автором досліджено питання щодо використання мережі Інтернет у передвиборній агітації.

Ключові слова: передвиборна агітація, форми та засоби передвиборної агітації, вибори народних депутатів України, вибори депутатів парламенту.

В статье поднимается вопрос о роли предвыборной агитации на парламентских выборах. Рассмотрены формы и способы ее осуществления на выборах народных депутатов Украины, которые предусмотрены и довольно подробно урегулированы Законом Украины «О выборах народных депутатов Украины», такие как: митинги, шествия, демонстрации, пикеты, концерты, спектакли, спортивные соревнования, демонстрация фильмов и тому подобное. Автором исследован вопрос об использовании сети Интернет в предвыборной агитации.

Ключевые слова: предвыборная агитачия, формы и средства предвыборной агитации, выборы народных депутатов Украины, выборы депутатов парламента.

The article raises the question of the role of election campaigning in the parliamentary elections. The forms and means of its implementation in the elections of the People's Deputies of Ukraine, which are envisaged and regulated in detail by the Law of Ukraine "On Elections of the People's Deputies of Ukraine», are considered. carrying out forms of election campaigning, such as rallies, marches, demonstrations, pickets, concerts, performances, sports competitions, film and television screenings or other public events, today require a number of legislative normalization, as well as the role of election agitation in parliamentary elections. countries, the importance of election campaigning to shape the will of voters regarding their future choices and the composition of the legislature. The question of the need to improve the national electoral legislation regarding the regulation of election campaigning has also been raised, based on positive foreign experience in this field. This practice shows that there is a need for the adoption of the relevant law of Ukraine that would regulate the organization and organization of mass events (rallies, demonstrations, street campaigns) in Ukraine. Issues of concerts, performances, sports competitions, films and TV shows or other public events supported by a party subject to the election process or a candidate during the election campaign in the relevant Law of Ukraine "On Elections of the People's Deputies of Ukraine» need to be regulated in more detail. The author explores the issues regarding the use of the Internet in election campaigning. It is also noted that in order to ensure equal conditions and opportunities for election campaigning on the Internet, it is necessary to extend the requirements of the Law of Ukraine «On Elections of People's
Deputies of Ukraine» regarding the terms, subject composition and financing of election campaigning, as well as those restrictions that already enshrined in the electoral legislation in force.

Key words: election campaigning, forms and means of election campaigning, elections of people's deputies of Ukraine, elections of deputies of parliament.

Постановка проблеми та іï актуальність. Передвиборна агітація $\epsilon$ важливим елементом виборчої кампанії, завдяки якій визначається електоральний корпус учасників виборчих перегонів. Проте проведення таких форм передвиборної агітації в Україні на парламентських виборах, як мітинги, походи, демонстрації, пікети, концерти, вистави, спортивні змагання, демонстрація фільмів та телепередач чи інші публічні заходи, сьогодні потребують свого законодавчого удосконалення, оскільки відсутність їх чіткого законодавчого врегулювання має наслідком різноманітні зловживання в цій сфері.

Аналіз останніх досліджень і публікацій. Питанням передвиборної агітації присвячені праці таких учених: О. Большакова, С. Кальченко, Ю. Ключковського, Д. Ковриженко, О.Марцеляка, В. Фалькова, М. Фомінатаін.

Метою статті $\epsilon$ аналіз видів форм та засобів передвиборної агітації на парламентських виборах в Україні та в зарубіжних країнах і на цій основі вироблення пропозицій щодо вдосконалення вітчизняного виборчого законодавства в частині регулювання передвиборної агітації, виходячи з позитивного зарубіжного досвіду в цій сфері.

Виклад основного матеріалу. Законом України «Про вибори народних депутатів України» доволі детально врегульовані форми передвиборної агітації, які можна охарактеризувати як зовнішні прояви, конкретні дії, що здійснюються уповноваженими суб'єктами виборчого процесу з метою спонукати виборців голосувати чи не голосувати за тих чи інших кандидатів у народні депутати (списки кандидатів).

Поняття форми передвиборної агітації, на думку В.М. Фалькова, слід розглядати у двох аспектах - внутрішньому та зовнішньому. При цьому під внутрішньою формою передвиборної агітації він розуміє будову, певний спосіб структурної організації та зв'язку елементів змісту передвиборної агітації, а зовнішню форму інтерпретує як зовнішнє вираження внутрішньо організованого змісту цього явища. Головним структурно-організуючим способом зовнішнього вираження передвиборної агітації, як доводить учений, виступає виборче право, в нормах якого фіксуються елементи його змісту (цілі, строки, об'єкт, суб'єкти) та встановлюються їхні конкретні параметри [1, с. 15]. 
На наш погляд форми передвиборної агітації можна також класифікувати на такі, що охоплюють проведення масових акцій, та здійснення безпосереднього спілкування з виборцями.

Законом України «Про вибори народних депутатів України» доволі детально врегульовані форми передвиборної агітації. Зокрема, ч. 2 ст. 68 визначено, що передвиборна агітація може проводитися у таких формах:

1) проведення зборів громадян, інших зустрічей з виборцями;

2) проведення мітингів, походів, демонстрацій, пікетів;

3) проведення публічних дебатів, дискусій, «круглих столів», прес-конференцій стосовно положень передвиборних програм та політичної діяльності партій - суб'єктів виборчого процесу чи політичної діяльності кандидатів у депутати;

4) оприлюднення в друкованих та аудіовізуальних (електронних) засобах масової інформації політичної реклами, виступів, інтерв'ю, нарисів, відеофільмів, аудіо- та відеокліпів, інших публікацій та повідомлень;

5) розповсюдження виборчих листівок, плакатів та інших друкованих агітаційних матеріалів чи друкованих видань, в яких розміщено матеріали передвиборної агітації;

6) розміщення друкованих агітаційних матеріалів чи політичної реклами на носіях зовнішньої реклами;

7) проведення концертів, вистав, спортивних змагань, демонстрації фільмів та телепередач чи інших публічних заходів за підтримки партії - суб'єкта виборчого процесу чи кандидата у депутати, а також оприлюднення інформації про таку підтримку;

8) публічні заклики голосувати або не голосувати за партію - суб'єкта виборчого процесу, кандидата в депутати або публічні оцінки діяльності цих партій чи кандидатів у депутати;

9) встановлення агітаційних наметів;

10) в інших формах, що не суперечать Конституції та законам України [2].

Не будемо зупинятися на характеристиці всіх вищезазначених форм, оскільки обсяг наукової статті цього не дозволяє, а охарактеризуємо ті з них, які на практиці викликають проблеми з точки зору їх неналежного законодавчого врегулювання.

У цьому аспекті слід наголосити, що проведення таких форм передвиборної агітації, як мітинги, походи, демонстрації, пікети, концерти, вистави, спортивні змагання, демонстрація фільмів та телепередач чи інші публічні заходи, сьогодні потребують цілого ряду законодавчого унормування. Так, тривалий час проведення в Україні мітингів, походів, демонстрацій регулювалося ухвалою Президії Верховної Ради СРСР «Про порядок організації та проведення зборів, мітингів, вуличних походів і демонстрацій в СРСР» від 28 липня 1988 р., положення якої не відповідали ні ст. 39 Конституції України, ні визнаним світовою спільнотою міжнародним стандартам, про що Конституційним Судом України було прийнято відповідне рішення. Тому перед вітчизняним парламентом гостро стоїть завдання найближчим часом прийняти відповідний закон України, який би врегулював порядок організації та проведення масових заходів в Україні. Це важливо не тільки з точки зору унормування проведення зборів, мітингів, походів, демонстрацій у період передвиборної агітації, а й точки зору забезпечення проголошеного Конституцією України права громадян збиратися мирно, без зброї і проводити збори, мітинги, походи і демонстрації.

Якщо ж звернутися до практики зарубіжних країн з цього питання, то можна побачити, що окремі країни, такі як Австрія, Білорусь, Велика Британія та Італія, передбачають регулювання та нагляд за проведенням масових заходів, переважно громадсько-політичних, в окремому нормативному акті на рівні закону в межах двох підходів:

в державі існує загальний законодавчий акт, який визначає поняття масового заходу, порядок забезпечення громадського порядку і безпеки під час його проведення;

держава законом установлює порядок проведення окремих видів масових заходів, як правило, громадсько-політичних, адже саме вони $\epsilon$ найбільш проблемними в плані забезпечення правопорядку [3, с. 246-247].

Вважаємо перший підхід більш доцільним для вітчизняного будівництва. Інший аспект цієї проблематики полягає в тому, що відсутність чіткого законодавчого унормування порядку проведення концертів, вистав, спортивних змагань, демонстрації фільмів та телепередач чи інших публічних заходів за підтримки партії суб'єкта виборчого процесу чи кандидата у депутати має наслідком різноманітні зловживання у цій сфері. Що, до речі, характерно, і для інших країн. Наприклад, безкоштовна роздача виборцям квитків на концерт (як і на будь-який інший розважальний захід) у Російській Федерації являє собою підкуп виборців. Такої позиції дотримується, зокрема, російська Феміда, яка безкоштовні концерти, організовані кандидатом до представницького органу влади для виборців, розцінює як предмет підкупу (при цьому обов'язковою ознакою підкупу $\epsilon$ його здійснення за умови голосування «за» чи «проти» конкретного кандидата [4, с. 154].

Потребує врегулювання і питання, коли, наприклад, концерти артистів проходять одразу після зустрічі кандидатів із виборцями або перед початком їхньої зустрічі без оплати з коштів виборчого фонду, якщо вказані концерти $\epsilon$ складовою частиною проведення кандидатами передвиборної агітації. Внаслідок відсутності чіткого законодавчого врегулювання цього питання вітчизняній Феміді не завжди вдається довести причетність суб'єктів виборчого процесу до проведення концертів, вистав, спортивних змагань, демонстрації фільмів та телепередач чи інших публічних заходів у період виборчої кампанії [5, с. 532-533]. Український вчений В.О. Серьогін пише, що при цьому концерт має супроводжуватися закликами учасників концерту підтримати на виборах відповідного кандидата, розповсюдженням на концерті агітаційних передвиборних матеріалів, що закликають голосувати за кандидата, оголошенням положень його передвиборної програми. Сама ж присутність кандидата на концерті, організованому в періодпроведення виборів, неможебути визнана порушенням, якщо це безпосередньо не пов'язано з проведенням ним передвиборної агітації [6, с. 227].

Застосовується в зарубіжних країнах і така форма передвиборної агітації, як організація громадських приймалень, яка вперше була започаткована у США у 1896 р. і являє собою створення «груп інтересів», які працюють із різними верствами населення у своєрідних «офісах розбору претензій», в яких кандидати приймають виборців [7, с. 80]. 
Слід сказати, що і в Україні з 90-х років XX ст. запроваджена така форма передвиборної агітації, хоча законодавчо вона дотепер не унормована (виборче законодавство передбачає тільки встановлення агітаційних наметів). Громадські приймальні слугують постійно діючими пунктами розповсюдження агітаційних матеріалів, сприяють виявленню нових активістів виборчої кампанії кандидата та їх інтеграції у команду. Більшість відвідувачів приймалень становлять виборці, які звертаються з проханнями до учасників передвиборних перегонів щодо надання допомоги у вирішенні тих чи інших проблем [8, с. 289].

У зв'язку з цим виникає питання щодо законності такої форми передвиборної агітації та участі кандидатів у народні депутати в процесі розв'язання злободенних проблем виборців хоча б шляхом надання інформаційних послуг, чи коли в період передвиборної агітації у кандидатів відбуваються зустрічі з виборцями з нагоди якоїсь планової події за участю підлеглих осіб. У цьому вітчизняне виборче законодавство потребує свого вдосконалення.

Так само, на наш погляд, потребує законодавчого врегулювання статус агітаторів в Україні. Виборче законодавство України взагалі не оперує таким поняттям, і водночас на практиці вони $є$. Тому вважаємо, що слід урахувати зарубіжний досвід, наприклад, Великобританії, і законодавчо визначити статус агітаторів. Акт про народне представництво Великої Британії передбачає, що кандидати в депутати парламенту можуть залучати для ведення передвиборної агітації вербувальників (Canvassers), які зазвичай обходять будинки виборців чи іншим способом агітують за обрання того чи іншого кандидата. Вербувальники можуть здійснювати свою діяльність виключно на громадських засадах (ст. 111). Законодавство Індонезії теж передбачає, що в агітаційній кампанії можуть брати участь громадські волонтери, які мають право розсилати агітаційні матеріали, писати електронні листи та здійснювати телефонні дзвінки на користь того чи іншого кандидата.

Можна резюмувати, що в цілому передбачені Законом України «Про вибори народних депутатів України» форми передвиборної агітації відповідають зарубіжній практиці розвинутих демократичних країн. Але потрібно підкреслити, що законодавче закріплення такого повного переліку форм передвиборної агітації, як в Україні, в зарубіжній практиці зустрічається не так часто. Це пов'язано з домінуванням у міжнародній виборчій практиці принципу свободи проведення громадянами, політичними партіями, іншими громадськими об'єднаннями, кандидатами у депутати в будь-яких законних формах і методах агітаційної діяльності в умовах плюралізму думок і відсутності цензури, а також для гарантування широкого простору самостійній і творчій агітаційній діяльності учасників виборчої кампанії [9, с. 453]. Проте вважаємо, що визначені вітчизняним виборчим законодавством форми передвиборної агітації жодним чином не порушують принципу свободи агітації.

Водночас хочемо відзначити, що з розвитком новітніх технологій виникають все нові та нові способи донесення інформації до населення, які поступово витісняють традиційні способи. Не $\epsilon$ виключенням у цьому плані й поширення агітаційних матеріалів, які з розвитком інформаційного суспільства багато в чому визна- чають результативність виборчої кампанії. Як зазначає О. Зернецька, у країнах представницької демократії в останні 8-10 років штаби політичних партій та окремі політики дедалі більше долучають можливості нових медіа, зокрема Інтернету, до інструментарію своєї політичної боротьби. До вже традиційних можливостей електронної пошти, сайтів партій та окремих політиків додалися такі знаряддя, як мобільні телефони i/або відеокамери, які служать інструментами поширення аудіо- та відеоінформації, що в поєднанні з можливостями Інтернету легко потрапляють на сайти і блоги інтернет-спільноти [10, с. 19]

Не можна не погодитися з позицією російського дослідника А. Водолагіна про те, що Інтернет має суттєві переваги над традиційними ЗМІ, як-от: миттєвість опублікування будь-якої інформації; роль Інтернету як засобу політичного спілкування, а не тільки інформаційного поля; відсутність нестачі друкованої площі; відносно невелика вартість створення ресурсу [11, с. 50]. Це, на думку вітчизняного вченого Р. Коваленка, робить Інтернет найпривабливішим способом донесення інформації до потенційного електорату для відповідних суб'єктів виборчого процесу [12, с. 149]. Хоча водночас А. Водолагін справедливо говорить, що одним із головних феноменів Інтернету $\epsilon$ фактична передача здійснення контролю над створенням, поширенням та отриманням інформації від держави до людини [11, с. 50].

Р. Коваленко, підтримуючи цю позицію, розширює iii i пише, що звернення до Інтернету з метою ведення передвиборної агітації ставить багато викликів перед виборчим правом. Таке звернення може породжувати суперечності між конституційним правом на реалізацію свободи слова, з однієї сторони, та правом вільно збирати, зберігати, використовувати і поширювати інформацію усно, письмово або в інший спосіб - на свій вибір, з іншої. Окрім того, здійснення передвиборної агітації робить особливо вразливим принцип рівності кандидатів на певні виборні посади, а також право на невтручання в особисте життя виборців [12, с. 149]. У подальшому цей науковець звертає увагу, що зворотною стороною використання Інтернету для агітаційних цілей $є$ створення значних проблем у правозастосуванні для органів публічної влади - в Україні кандидати на певні виборні посади все частіше звертаються до можливостей Інтернету, аби обійти заборони фінансового та організаційного характеру, встановлені виборчим законодавством. До подібних висновків про надання Інтернетом значних можливостей як для забезпечення конституційних прав громадян на отримання i збір інформації, так і для зловживання цим правом доходить й І.М. Поспєлова [13, с. 148].

Виходячи з цього, а також з того, що проведення передвиборної агітації з використанням мережі Інтернет чинним виборчим українським законодавством не забороняється з огляду на невиключний перелік допустимих форм агітації, встановлених виборчими законами (і парламентські вибори 2019 року $є$ яскравим свідченням цього), перед вітчизняним законодавцем постає відповідальне завдання - встановити чіткі правові межі використання Інтернету для ведення передвиборної агітації, за яких зловживання в Інтернеті під час агітації зводилися би до мінімуму.

На думку вже згадуваного нами вітчизняного вченого Р. Коваленка, серед можливих ризиків, які поро- 
джує використання Інтернету з метою передвиборної агітації, можна виділити такі: можливість обходу існуючої для ЗМІ заборони щодо недопущення проведення передвиборної агітації з використанням зарубіжних 3Ml;

ускладнена неможливість захисту честі, гідності, ділової репутації певного кандидата на виборну посаду чи політичної партії;

неможливість запобігти передчасній агітації та агітації після закінчення допустимого строку на $\dddot{1}$ здійснення [12, с. 149-150].

Цілком можна до числа таких ризиків віднести й те, що в разі використання Інтернету з метою передвиборної агітації неможливо забезпечити здійснення належного фінансування розміщення агітаційних матеріалів в Інтернеті. По-перше, на відміну від використання друкованих та аудіовізуальних ЗМІ, коли на суб'єктів виборчого процесу поширюється вимога щодо конкретних джерел фінансування розміщення агітаційних матеріалів, з необхідністю обов'язкового договірного оформленням відносин між таким ЗМІ та замовником розміщення матеріалів, при використанні мережі Інтернет дані вимоги не поширюються. По-друге, якщо для друкованих та аудіовізуальних 3МІ вимоги до ціноутворення чітко прописані на рівні Закону України «Про вибори народних депутатів України», то щодо використання Інтернету таких вимог ціноутворення за надання інформаційного простору для розміщення певних агітаційних матеріалів немає. Тобто питання оплати агітаційних послуг через мережу Інтернет законодавчо не врегульовано, що як знижує прозорість фінансування здійснення передвиборної агітації суб'єктів виборчого процесу, так і сприяє зловживанням у цій сфері.

Також до числа ризиків використання Інтернету з метою передвиборної агітації можна віднести й те, що в разі поширення висловлювань в Інтернеті, особливо в блогах, соціальних мережах, інколи важко ідентифікувати автора чи довести, що саме конкретна особа, авторство якої зазначено в висловлюванні, насправді поширила це висловлювання, внаслідок частої анонімності такого автора (використання псевдоніму) або ж імовірності зламу блогу особи через хакерську атаку.

Не слід залишати поза увагою й той факт, що внаслідок відсутності регулювання здійснення передвиборної агітації в Інтернеті порушується принцип рівності, оскільки ті кандидати в народні депутати та політичні сили, які здійснюють передвиборну агітацію через мережу Інтернет, отримують конкурентні переваги порівняно з політичними партіями та кандидатами, які використовують виключно традиційні шляхи поширення політичної інформації.

Усе зазначене доводить висновку, що національний законодавець має якнайшвидше врегулювати питання здійснення перевиборної агітації через мережу Інтернет. Проте ради об'єктивності зазначимо, що світова практика свідчить, що детальна нормативна регламентація зазначеного вище питання не така уже однозна- чна й ефективна. Зокрема, можна послатися у цьому питанні на досвід США, де Верховний Суд на підставі першої поправки в 1996 році скасував закон про регулювання Інтернету. Натомість у Франції у вересні 1998 р. була видана спеціальна доповідь Державної ради про юридичні питання, пов'язані з використанням Інтернету, де автори цієї доповіді теж дійшли висновку про відсутність необхідності створювати окреме правове поле для Інтернету, однак уже виходячи з того, що всі питання поширення інформації через Інтернет уже врегульовані іншими спеціальними законами [14, с. 21].

Український фахівець М. Бучин теж стверджує, що в умовах використання для цілей передвиборної агітації мережі Інтернет важко дотримуватися вимог щодо всіх необхідних вихідних даних, які ставляться до звичайних агітаційних матеріалів [15, с. 143].

Тому за законодавчого врегулювання питання здійснення передвиборної агітації через мережу Інтернет варто виходити з того, що воно має відбуватися на рівні профільного виборчого законодавства. Це буде найбільш ефективний підхід, який сприятиме мінімізації зловживань у цій сфері, урахуванню специфіки здійснення передвиборної агітації, сприятиме забезпеченню принципу рівності у виборчій кампанії. Ми погоджуємося з І.М. Поспєловою про те, що нормативне регулювання передвиборної агітації в Інтернеті в Україні має відбуватися на основі принципів: а) забезпечення прав і свобод людини та громадянина, встановлених Конституцією та міжнародними актами; б) використання правил та звичаїв, які склалися у співтовариствах операторів та користувачів мережі Інтернет, якщо вони не суперечать законодавству [13, с. 148].

Окрім того, вважаємо, що з метою забезпечення рівних умов та можливостей здійснення передвиборної агітації на передвиборну агітацію в мережі Інтернет необхідно поширити вимоги Закону України «Про вибори народних депутатів України» щодо строків, суб'єктного складу та фінансування передвиборної агітації, а також ті обмеження, які вже зараз закріплені в чинному виборчому законодавстві.

Висновки. Таким чином, характеристика вітчизняної практики та зарубіжного досвіду щодо проведення передвиборної агітації на виборах депутатів парламенту засвідчують, що має місце потреба у прийнятті відповідного закону України, який би врегулював порядок організації та проведення масових заходів (мітингів, демонстрацій, вуличних походів) в Україні. Потрібно більш детально врегулювати питання проведення концертів, вистав, спортивних змагань, демонстрації фільмів та телепередач чи інших публічних заходів за підтримки партії - суб'єкта виборчого процесу чи кандидата в депутати під час передвиборної агітації в профільному Законі України «Про вибори народних депутатів України». Також вітчизняному законодавцю варто, все ж таки, на рівні профільного законодавства врегулювати новітні форм передвиборної агітації, в тому числі через Інтернет. 


\section{Література}

1. Фальков В.Н. Совершенствование правового регулирования передвыборной агитации в Российской Федерации : дис. ... канд. юрид. наук : 12.00.02. Тюмень, 2003. 241 C.

2. Про вибори народних депутатів : Закон України від 17.11.2011 p. № 4061-VI. URL: http://zakon3.rada.gov.ua/ laws/show/4061-17 (дата звернення: 13.11.2019).

3. Стеценко С. Обмеження права на свободу зібрання в законодавстві зарубіжних країн. Проблеми державотворення і захисту прав людини в Україні : зб. наук. пр. за матер. XIII регіон. наук.-практ. конф., 8-9 лют. 2007 р. Львів : Вид-во юр. Ф-ту Львів. нац. ун-ту ім. І. Франка, 2007. С. 246-248.

4. Аглеева Л.Т. Предвыборная агитация в избирательном праве Российской Федерации (вопросы теории и практики) : дис. ... канд. юрид. наук : 12.00.02. Екатеринбург, 2006. 189 с.

5. Збірник рішень судів за результатами розгляду скарг і заяв суб'єктів виборчого процесу з виборів депутатів Верховної Ради АРК, місцевих рад та сільських, селищних та міських голів 2006 року / Я.В. Давидович та ін. Київ : Атіка, 2007. 744 с.

6. Серьогін В.О. «Політичне прайвесі» у виборчому процесі: Україна і закордонний досвід. Вибори 2006: Досвід. Проблеми. Перспективи : зб. матеріалів міжнар. наук.-практ. конф., Київ, 31 жовт. - 1 лист. 2006 р. Київ : Атіка, 2007. 457 c.

7. Овчинникова М.А. Связи с общественностью как технология президентской власти в США : дис. ... канд. полит. наук : 23.00.02. Москва, 2002. 248 с.
8. Малкін Є.Б. Основи виборчих технологій та партійного будівництва. Київ : Основні цінності, 2005. 528 с.

9. Марцеляк О.В. Вибори народних депутатів України: історія, теорія, практика : навчальний посібник. Харків : ТОВ «ПРОМЕТЕЙ-ПРЕС», 2008. 636 с.

10. Зернецька О. Глобальна політична блогосфера нова арена політичної комунікації. Політичний менеджмент. 2009. № 2. С. 13-26.

11. Водолагин А.А. Интернет-СМИ как арена политической борьбы. Общественные науки и современность. 2002. № 1. С. 49-67.

12. Коваленко Р.О. Передвиборна агітація на виборах президентів України та США: конституційно-порівняльне дослідження : дис. ... канд. юрид. наук : 12.00 .02 ; Нац. ун-т «Од. юр. акад.». Одеса, 2017. 200 с.

13. Поспєлова І.М. Конституційно-правове регулювання передвиборної агітації : дис. ... канд. юрид. наук : 12.00.02 ; Інститут законодавства ВРУ. Київ, 2016. 192 С.

14. Іванов В. Правове регулювання Інтернет. Деякі аспекти. Свобода висловлювань і приватність. 2002. № 3. С. 21-27.

15. Бучин М. Використання інформаційних технологій під час виборчого процесу як елемент електронної демократії. Інформація, комунікація, суспільство 2013 : мат. 2-ої Міжн. каук. конф. ІКС-2013, 16-19 травня 2013 р. ; Нац. Ун-т «Львівська політехніка». Львів : Вид-во Львів. політехніки, 2013. С. 142-143.

Волошенюк Н. М., aсnірант ДВНЗ «Ужгородський національний університет» 